
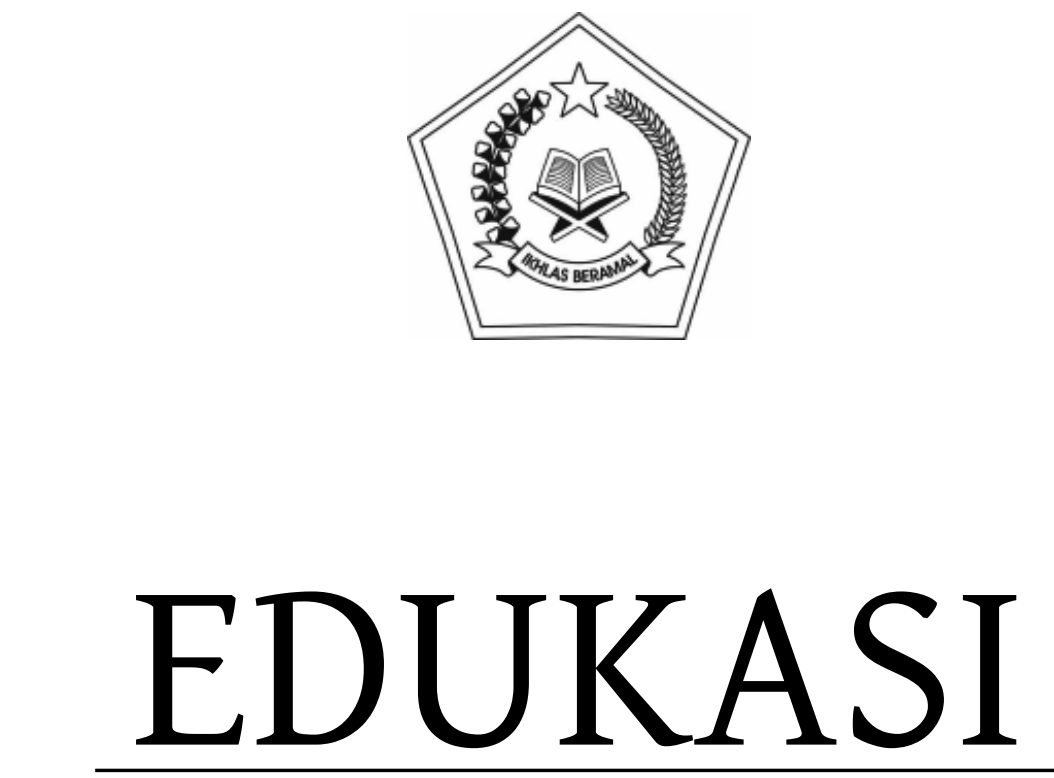

JURNAL PENELITIAN PENDIDIKAN AGAMA DAN KEAGAMAAN

VOLUME 13, NOMOR 3, DESEMBER 2015 


\title{
PESANTREN AT-TAUBAH DI LEMBAGA PEMASYARAKATAN KELAS II B CIANJUR
}

\section{PESANTREN AT-TAUBAH AT PENITENTIARY OF CLASS II B CIANJUR}

\author{
Ta'rif \\ Puslitbang Pendidikan Agama dan Keagamaan \\ Badan Litbang dan Diklat Kemenag RI \\ Jl. MH Thamrin No. 06 Jakarta Pusat \\ Email: ta75rif@gmail.com \\ Husen Hasan Basri \\ Puslitbang Pendidikan Agama dan Keagamaan \\ Badan Litbang dan Diklat Kemenag RI \\ Jl. MH Thamrin No. 06 Jakarta Pusat \\ Email: hhasanbasri@yahoo.com
}

Naskah diterima 10 Oktober 2015, direvisi 8 Desember 2015, disetujui 15 Desember 2015

\begin{abstract}
A displacement of the imprisonment to the penitentiary replaces the term of prisoner becomes penitentiary-developed resident. The penitentiary system is oriented on the efforts of preservation, development, education and up-building. One of the development forms for the developed resident is the development and up-building on mental and religious education. The penitentiary of Class II $B$ Cianjur conducts at-Taubah boarding school. Where and what kind of position for at-Taubah Boarding School at the Penitentiary and how the religious education is conducted. Through qualitative method, it is found that at-Taubah boarding school is established by one of the developed residents and the Penitentiary itself. It concluded that at-Taubah boarding school constitutes a therapy boarding school and religious education in the frame of establishment of the Moslem personality.
\end{abstract}

Keywords: boarding school, penitentiary, developed resident
Abstrak

Pergeseran kepenjaraan kepada lembaga pemasyarakatan menggantikan sebutan narapidana menjadi warga binaan pemasyarakatan. Sistem pemasyarakatan berorientasi kepada usaha perawatan, pembinaan, pendidikan, dan bimbingan. Salah satu bentuk pembinaan bagi warga binaan adalah pembinaan dan bimbingan mental kerohanian dan pendidikan agama. Lapas Kelas II B Cianjur menyelenggarakan pesantren at-Taubah. Dimana apa posisi pesantren at-Taubah di Lapas dan bagaimana penyelenggaraan pendidikan agama. Melalui metode kualitatif, ditemukan bahwa pesantren at-Taubah didirikan oleh salah satu warga binaan dan pihak Lapas. Pesantren at-Taubah terpadu dengan pembinaan di Lapas. Disimpulkan bahwa pesantren at-Taubah merupakan pesantren terapi dan pendidikan keagamaan dalam rangka pembentukan kepribadian muslim.

Kata Kunci: pesantren, pemasyarakatan, warga binaan 


\section{PENDAHULUAN}

Semenjak ditetapkannnya Undangundang no. 12 tahun 1995 tentang Pemasyarakatan, masalah pembinaan narapidana di Indonesia mengalami perubahan yang cukup signifikan dari sistem kepenjaraan yang mengacu pada Reglemen Penjara 1917 No.708 kepada sistem pemasyarakatan. Istilah penjara dengan sistem kepenjaraan yang dulunya terkesan angker dan sangar sebagai tempat hukuman itu kini menjadi terdengar lebih 'ramah' dan 'manusiawi' setelah diganti dengan istilah Lembaga Pemasyarakatan dengan sistem pemasyarakatan. Sebutan nara $\neg$ pidana pun diganti dengan Warga Binaan Pemasyarakatan (WBP).

Dalam UU tersebut, sistem pemasyarakatan dimaksudkan sebagai upaya yang menitikberatkan pada usaha perawatan, pembinaan, pendidikan, dan bimbingan bagi warga binaan (narapidana) yang bertujuan untuk memulihkan kesatuan hubungan yang asasi antara individu warga binaan dan masyarakat. Sistem pemasyarakatan diselenggarakan dalam rangka membentuk Warga Binaan Pemasyarakatan (WBP) agar menjadi manusia seutuhnya, menyadari kesalahan, memperbaiki diri, dan tidak mengulangi tindak pidana sehingga dapat diterima kembali oleh lingkungan masya-rakat, dapat aktif berperan dalam pembangunan, dan dapat hidup secara wajar sebagai warga yang baik dan bertanggung jawab. Pelaksanaan pembinaan pemasyarakatan didasarkan atas prinsip-prinsip sistem pemasyarakatan untuk merawat, membina, mendidik dan membimbing warga binaan dengan tujuan agar menjadi warga yang baik dan berguna. ${ }^{1}$

${ }^{1}$ UU no.12 tahun 1995 tentang Pemasyarakatan dan Penjelasan PP no. 32 tahun 1999 tentang Syarat dan Tata Cara Pelaksanaan Hak Warga Binaan Pemasyarakatan.
Dengan prinsip pembinaan, pendidikan dan bimbingan, warga binaan di dalam Lembaga Pemasyarakatan tidak lagi diperlakukan sebagai pihak terhukum yang layak untuk dikucilkan, dihukum dan disiksa, tetapi mereka kini menjadi seperti 'anak didik' yang diberikan pendidikan, pembinaan dan bimbingan. Hak-hak warga binaan sebagai warga negara dalam sistem pemasyarakatan sebagaimana diamanatkan UU tersebut tetap terjaga. ${ }^{2}$

Sebagai bentuk implementasi dan prosedur teknis pelaksanaan, UU no. 12 tahun 1995 kemudian dilengkapi dan disempurnakan dengan Peraturan Pemerintah no. 32 tahun 1999 tentang Syarat dan Tata Cara Pelaksanaan Hak Warga Binaan Pemasyarakatan. Dalam PP ini, tata cara pemenuhan hak warga binaan dijelaskan secara detail. Misalnya, hak mendapatkan perawatan rohani dan jasmani, Pasal 6 menjelaskan bahwa untuk memenuhi hak pendidikan rohani warga binaan, pihak Lapas harus menyediakan petugas pembina dan pembimbing rohani dan pendidikan budi pekerti juga terkait hak warga binaan untuk mendapatkan

2 Setidaknya ada empat belas macam hak warga binaan yang termaktub didalam UU tersebut, yakni hak melakukan ibadah sesuai dengan agama atau kepercayaannya; mendapat perawatan, baik perawatan rohani maupun jasmani; mendapatkan pendidikan dan pengajaran; mendapatkan pelayanan kesehatan dan makanan yang layak; menyampaikan keluhan; mendapatkan bahan bacaan dan mengikuti siaran media massa lainnya yang tidak dilarang; dan mendapatkan upah atau premi atas pekerjaan yang dilakukan. Selain itu, juga ada hak menerima kunjungan keluarga, penasihat hukum, atau orang tertentu lainnya; mendapatkan pengurangan masa pidana (remisi); mendapatkan kesempatan berasimilasi termasuk cuti mengunjungi keluarga; mendapatkan pembebasan bersyarat; mendapatkan cuti menjelang bebas; dan mendapatkan hak-hak lain sesuai dengan peraturan perundang-undangan yang berlaku. Lihat pasal 14 UU no.12 tahun 1995 tentang Pemasyarakatan. 
pendidikan dan pengajaran, pasal 10 PP ini menyebutkan bahwa disamping menyediakan tenaga pendidik, pihak Lapas juga dianjurkan untuk menjalin kerjasama baik dengan instansi pemerintah maupun lembaga-lembaga kemasyarakatan guna optimalisasi pemenuhan hak pendidikan dan pengajaran warga binaan.

Salah satu bentuk pembinaan yang cukup vital bagi warga binaan adalah pembinaan dan bimbingan mental kerohanian dan pendidikan agama. Hal ini terutama karena kesiapan warga binaan untuk kembali ke tengah-tengah masyarakat dan kemungkinan tidak mengulangi tindak kejahatan yang telah dilakukannya sangat tergantung dari bagaimana proses pembinaan dan bimbingan mental kerohanian yang ia jalani selama di dalam Lapas. Dalam upaya optimalisasi pembinaan dan bimbingan mental kerohanian ini, banyak model yang dilakukan pihak Lapas. Salah satu model yang dikembangkan pihak Lapas dalam pembinaan mental rohani (pembinaan kepribadiaan) warga binaan adalah melalui penyelenggaraan pesantren. Salah satu-mungkin satu-satunya-Lapas yang menyelenggarakan model pesantren adalah Lapas Kelas II B Cianjur.

Menurut Kepala Lembaga Pemasyarakatan Kelas II B Cianjur, Tri Saptono Sambudji, kehadiran pondok pesantren di Lapas merupakan bagian dari pembinaan para narapidana yang kelak akan kembali ke lingkungan masyarakat. ${ }^{3}$ Keberadaan pesantren di Lapas Kelas II B Cianjur mendapat respon positif dari berbagai kalangan, karena model Pondok Pesantren Terpadu At-Taubah di Lembaga Pemasyarakatan Kelas II B Cianjur cukup berhasil. Keberhasilan pengelolaan

3 Wawancara dengan Kasubsi Registrasi dan Bimkemas Lapas kelas II B Cianjur, Mastur SH, pada 4 Februari 2013 pembinaan narapidana itu menginspirasi Menteri Agama saat itu, Surya Dharma Ali, untuk mendorong dibuatnya pondok pesantren di lingkungan lembaga pemasyarakatan di seluruh Indonesia. Sebab, sebagai tempat pembinaan, akan lengkap peran dan fungsi penjara, membina narapidana dalam konteks keagamaan dan keimanan.

Gagasan tentang pondok pesantren at-Taubah Lapas kelas IIB Cianjur dapat dijadikan model untuk dicoba diterapkan di Lapas lainnya perlu diterjemahkan dalam bentuk yang kongkrit dan implementatif. Ketika kasus pesantren At-Taubah ini diimplementasikan muncul beberapa permasalahan, yaitu: pertama, terkait dengan posisi pesantren di Lapas. Dimana posisi pesantren dalam institusi Lapas, apakah terpisah atau bagian yang terintegrasi dengan program pembinaan Lapas. Kedua, permasalahan yang terkait penyelenggaran pendidikan agama di pesantren at-Taubah. Permasalahan ini terkait dengan potret pendidikandipesantren at-Taubah, meliputi: penggagas, pengasuh dan pengajar, santri, kurikulum dan model pembelajaran, sarana prasarana, serta pembiayaan.

\section{Kerangka Pemikiran}

Penghapusan sistem kepenjaraan oleh sistem pemasyarakatan menjadikan perlakukan terhadap narapidana bersifat membina dan mendidik. Tujuan sistem pemasyarakatan sebagaimana diatur dalam Undang-Undang Nomor 12 Tahun 1995 tentang Pemasyarakatan, Pasal 2 menegaskanbahwa:"Sistempemasyarakatan diselenggarakan dalam rangka membentuk warga binaan pemasyarakatan agar menjadi manusia seutuhnya, menyadari kesalahan, memperbaiki diri dan tidak mengulang tindak pidana sehingga dapat diterima kembali oleh lingkungan masyarakat, dapat aktif berperan dalam pembangunan, dan 
dapat hidup secara wajar sebagai warga yang baik dan bertanggung jawab". ${ }^{4}$

Selanjutnya dalam Pasal 3 UndangUndang Nomor 12 Tahun 1995 tentang Pemasyarakatan disebutkan bahwa sistem pemasyarakatan berfungsi menyiapkan Warga Binaan Pemasyarakatan agar dapat berintegrasi secara sehat dengan masyarakat, sehingga dapat berperan kembali sebagai anggota masyarakat yang bebas dan bertanggung jawab. Dalam penjelasan Undang-Undang tersebut bhawa yang dimaksud dengan "berintegrasi secara sehat" pada Pasal 3 adalah pemulihan kesatuan hubungan Warga Binaan Pemasyarakatan dengan masyarakat.

Sistem Pemasyarakatan di samping bertujuan untuk mengembalikan Warga Binaan Pemasyarakatan sebagai warga yang baik juga bertujuan untuk melindungi masyarakat terhadap kemungkinan diulanginya tindak pidana oleh Warga Binaan Pemasyarakatan, serta merupakan penerapan dan bagian yang tak terpisahkan dari nilai-nilai yang terkandung dalam Pancasila. Dalam sistem pemasyarakatan, narapidana, anak didik pemasyarakatan berhak mendapatkan pembinaan rohani dan jasmani serta dijamin hak-hak mereka untuk menjalankan ibadah.

Dalam Peraturan Pemerintah Nomor 31 Tahun 1999 tentang Pembinaan dan Pembimbingan Warga Binaan Pemasyarakatan, pasal 1 dinyatakan bahwa pembinaan adalah kegiatan untuk meningkatkan kualitas ketaqwaan kepada Tuhan Yang Maha Esa, intelektual, sikap dan perilaku, profesional, kesehatan jasmani dan rohani Narapidana dan Anak Didik Pemasyarakatan.

Menurut A. Fuad Usfa sebagaimana yang dikutip Yuanita, teori pembinaan

4 Lihat UU No.12 Tahun 1995 tentang Pemasyarakatan pasal 2. lebih mengutamakan perhatiannya pada si pelaku tindak pidana, bukan pada tindak pidana yang telah dilakukan. Pidana tidak didasarkan pada berat ringannya tindak pidana yang dilakukan, melainkan harus didasarkan pada keperluan yang dibutuhkan untuk dapat memperbaiki si pelaku tindak pidana. Menurut teori ini tujuan pidana untuk merubah tingkah laku dan kepribadian si pelaku tindak pidana agar ia meninggalkan kebiasaan jelek yang bertentangan dengan norma hukum serta norma lainnya agar supaya ia lebih cenderunng untuk mematuhi norma yang berlaku. Dengan kata lain tujuan pidana adalah untuk memperbaiki pelaku tindak pidana. ${ }^{5}$

Dengan menggunakan konsepsi pembinaan, Yuanita mengkaji pembinaan nara pidana melalui pendidikan agama di lapas Narkotika Yogyakarta. Kajian itu menyimpulkan: pertama, kegiatan pembinaan narapidana melalui pendidikan agama sebagai upaya mencegah munculnya residivis di Lembaga Pemasyarakatan Narkotika Yogyakarta dilakukan melalui kerja sama dengan Kementrian Agama Kabupaten Sleman dan pondok pesantren.

kedua, terdapat kendala internal dan eksternal pembinaan narapidana melalui pendidikan agama. Kendala internal yang berasal dari dalam Lembaga Pemasyarakatan Narkotika Yogyakarta, berupa kendala internal fisik dan non fisik. Kendala eksternal yang berasal dari pihak luar, yaitu ketika narapidana bebas dari lembaga pemasyarakatan dimungkinkan kembali ke lingkungan penyalahguna narkotika seperti semula dan sistem pengawasan hanya pada

\footnotetext{
5 Lihat Rani Yuanita. 2011. Pembinaan Narapidana Melalui Pendidikan Agama sebagai Upaya Mencegah Munculnya Residivis di Lembaga Pemasyarakatan Narkotika Yogyakarta. Disertasi Fakultas Ilmu Sosial UNY
} 
saat narapidana berada di dalam lembaga pemasyarakatan.

Ketiga,upayaLapasNarkotikaYogyakarta untuk mengatasi kendala internal yaitu dengan pengadaan buku-buku keagamaan dan mempercepat proses administrasi pengadaan kelas, penyediaan waktu khusus bagi narapidana untuk berkunjung ke perpustakaan dan meningkatkan kesadaran narapidana dalam mengikuti pembinaan dengan mengoptimalkan penyadaran dalam setiap pembinaan yang dilakukan, melakukan pendekatan khusus kepada narapidana di luar pembinaan secara umum, melakukan perencanaan pembuatan kurikulum, menggunakan pendekatan personal kepada narapidana perempuan, menggunakan pendekatan konseling, media poster/gambar, serta penyediaan fasilitas perpustakaan, bekerjasama denganinstansi/ Lembaga Swadaya Masyarakat sebanyakbanyaknya, upaya diskusi antara Kasubsi Bidang Pembinaan dan Kasubsi Bidang Keamanan, serta penegakan komitmen petugas. Sedangkan untuk mengatasi kendala eksternal yaitu dengan memutus ketergantungan terhadap narkotika melalui rehabilitasi, pembinaan dan pencegahan pemakaian narkotika di dalam lapas; serta melakukan kerjasama dengan aparat hukum dan instansi lain yang terkait. ${ }^{6}$

Jika hasil kajian Yuanita menempatkan lembaga pesantren berada di luar Lapas dan sebagai partner Lapas, maka pesantren atTaubah di Lapas kelas II B Cianjur berada di dalam Lapas sendiri. Eksistensi pesantren di Lapas dapat dikatakan sebagai fenomena baru. Sebagai sebuah lembaga pendidikan dan keagamaan, pesantren at-Taubah Lapas

${ }^{6}$ Rani Yuanita. 2011. Pembinaan Narapidana Melalui Pendidikan Agama sebagai Upaya Mencegah Munculnya Residivis di Lembaga Pemasyarakatan Narkotika Yogyakarta. Disertasi Fakultas Ilmu Sosial UNY. kelas II B Cianjur memiliki peran-peran kependidikan dan keagamaan.

Lembaga Pemasyarakatan (Lapas) Klas II B Cianjur berdiri sejak tahun 1951. Semula beralamat di jalan Siliwangi. Kemudian pada tahun 1958 pindah ke jalan Aria Cikondang No. 75 Cianjur. Sebelum menjadi Lapas, ia adalah Rumah Tahanan (Rutan) Negara Klas II B Cianjur. Perubahan status Rutan menjadi Lapas terhitung mulai tanggal 16 April 2003. Lapas Klas II B Cianjur menempati lahan seluas $15.500 \mathrm{~m}^{2}$ dengan luas bangunan $2.560 \mathrm{~m}^{2}$. Daya tampung 500 orang dan saat ini menampung 870 warga binaan.

Perubahan status Rutan ke Lapas ini berdampak pada perubahan penanganan kepada narapidana, dari hukuman kepada pembinaan. Maka, narapidana tidak disebut sebagai orang-orang terhukum melainkan warga binaan dengan fokus pada pembinaan mental, pendidikan dan keterampilan kerja.

Pembinaan, bimbingan, dan pendidikan mental di Lapas Klas IIB diselenggarakan oleh Seksi Bimbingan Kemasyarakatan (Sie BIMKEMAS) di bawah koordinasi Kepala Bagian Pembinaan Narapidana/ Warga Binaan/Anak Didik. Sie BIMKEMAS selanjutnya menugaskan dua orang petugas Bimbingan Mental (Bintal) untuk urusan teknis pelaksanaannya. Bintal inilah yang sesungguh ᄀnya menjadi ujung tombak dan berada di garis depan yang paling menentukan berhasil tidaknya segala proses pelaksanaan bimbingan mental kerohanian. Demi optimalisasi capaian target pembinaan dan sebagaimana diamanatkan oleh UU No.12 tahun 1995 tentang Pemasyarakatan dan PP No. 32 tahun 1999 tentang Syarat dan Tata Cara Pelaksanaan Hak Warga Binaan Pemasyarakatan, Lapas membangun kerjasama dengan berbagai pihak seperti dengan Kementerian Agama, kepolisian dan BNN, dan mubaligh untuk membantu kinerja petugas Bintal. 
Mereka memberi penyuluhan dalam bentuk ceramah umum selama 2 jam setiap minggu. Materi yang disampaikan sesuai kelembagaan masing-masing. Kemenag memberikan pembinaan dalam hal keagamaan, Kepolisian memberikan pembinaan dalam kamtibmas, BNN memberikan penyuluhan tentang bahaya narkotika.

Seiring perkembangan peningkatan pelayanan pembinaan warga binaan Lapas danantusiasmewargabinaanyang mengikuti program pembinaan kegamaan tersebut, muncullah gagasan untuk meningkatkan proses pembinaan dengan membuat semacam pusat pembinaan sehingga yang dulunya dilakukan secara kuantitas jarang menjadi tinggi intensitasnya dalam 3 (tiga) bentuk pembinaan, yaitu: pembinaan keperibadian seperti pesantren terpadu atTaubah, pembinaan kemandirian seperti keterampilan, dan pembinaan intelektual seperti program paket $B$ dan paket $C$.

\section{METODOLOGI PENELITIAN}

Lokasi penelitian dilakukan di pesanteren Terpadu At-Taubah Lapas Kelas IIB Kabupaten Cianjur. Pengumpulan data dilakukan pada Tahun 2013. Penelitian menggunakan metode kualitatif dengan jenis kasus. Sumber data penelitian ini adalah pihak Lapas (Kasubsi Registrasi dan Bimkemas), MUI (sekretaris MUI), Kemenag (Kepala Kemenag, Kasi PD dan Pontren), pengasuh pesantren At-Taubah (KH.T. Mukhtar Ghozali), Rais 'Am pesantren sekaligus santri (Heri Sukirman, SH), ustadz dan santri (WB).

Wawancara degan Kasubsi Registrasi dan Bimkemas untuk mendapatkan data tentang pembinaan pendidikan agama di Lapas. Data tentang peran MUI dalam pembinaan diLapas didaparkan dari Sekretaris MUI Kabupaten Cinajur.Pengasuh pesantren diwawncarai untuk mendapatan data latar belakang berdiri dan penyelenggaraan pendidikan agama. Rais 'Am pesantren diwawancarai untuk mendapatkan data tentang layanan pendidikan agama sebelum dan setelah pesantren at-Taubah berdiri. Wawancara dengan ustadz dilakukan untuk memperoleh profil ustadz. Beberapa santri diwawancarai untuk mengetahui latar belakang dan keinginan memperoleh pendidikan agama. Selain wawancara, dilakukan observasi terhadap kegiatan keagamaan seperti shalat berjamaah, pengajian, belajar kelompok di setiap kamar.

Untuk pengolahan dan analisa data, penelitian ini menggunakan kata-kata kunci dari berbagai jawaban yang disampaikan informan atas aneka pertanyaan yang diajukan dalam wawancara. Kata-kata kunci tersebut akan diuraikan secara lebih rinci dan mendalam sebelum peneliti memberikan interpretasi atas data yang disampaikan informan tersebut. Selanjutnya, peneliti menjelaskan data itu dengan menggunakan konsep-konsep yang terkait dengan pemasyarakatan dan pesantren. Pengkodean (koding) dan analisis data adalah dua kegiatan yang dilakukan dalam analisis data.

\section{HASIL DAN PEMBAHASAN}

\section{Pendirian Pesantren Terpadu At-Taubah Lapas Klas IIB Cianjur}

Pesantren Terpadu At-Taubah Lembaga Pemasyarakatan (Lapas) Klas IIB Cianjur didirikan pada 20 Mei 2012. Penggagas awalnya dua orang, yakni HS (narapidana atau warga binaan) dan Deden Hendra $\mathrm{SH}$, Kasubsi Regristrasi dan Bimkemas. Gagasan ini dilatari oleh kegelisahaan akan pendekatan kekerasan dalam pembinaan yang dirasakan oleh warga binaan. Serta inefektivitas pengajian yang dilakukan dua minggu sekali dalam bentuk majelis ta'lim. 
Gagasan ini kemudian disampaikan kepada Kalapas saat itu, Sahad Philip Parapat. Meskipun Kalapas seorang Katolik, ia menyetujui urgensi pendirian pesantren sebagai upaya pembinaan terpadu.

Kebutuhan akan pendirian pesantren juga didasari oleh kegelisahan Deden Hendra yang melihat kesungguhan Dewan Gereja Cianjur dalam membina narapidana nashrani. Setiap sabtu, sebanyak 15 perwakilan Dewan Gereja yang membina 9 orang narapidana nashrani. Sementara pembinaan atas sebagian besar warga binaan muslim hanya terhenti pada majelis ta'lim seminggu dua kali. Maksimalitas pembinaan dari para pemuka nashrani dan minimalitas pembinaan kaum muslim inilah yang membuahkan gagasan pendirian pesantren. Saat ini, masih terdapat 1 warga binaan nahsrani yang tetap mendapatkan hak pembinaan keagamaan dari Dewan Gereja.

Di dalam proses pendirian pesantren, faktor HS sangat signifikan. Sebab dialah penggagas dan motor penggerak ide adanya pembinaan agama yang lebih baik. HS sendiri mantan Wakil Ketua DPRD Cianjur yang masuk Lapas akibat tersandung kasus korupsi. Ia divonis 7,5 tahun penjara dan sampai saat ini telah menjalani hukuman selama 3,5 tahun. Karena kasus korupsi yang menimpanya bersifat strukturalkebijakan, maka keberadaan HS di Lapas mendapat perhatian siginifikan dari temantemannya. Maka, dengan posisi strategis seperti itu, HS masih memiliki hubungan baik sehingga bisa mengupayakan alokasi dana bagi pendirian pesantren Lapas, baik dari pemerintah daerah maupun DPRD. Menariknya, ia menderivasikan alokasi dana ini dari Peraturan Daerah Gerbang Marhamah (Gerakan Masyarakat Berakhlaqul Karimah), di mana HS ikut merumuskan kebijakan ini saat ia menjabat. Maka, dengan terkumpulnya stakeholder baik dari Bupati, DPRD dan Majelis Ulama Indonesia (MUI) Cianjur, Pesantren AtTaubah bisa berdiri.

Dari "faktor HS" ini terlihat sulitnya pendirian pesantren di Lapas, yang membutuhkan dukungan struktural, khususnya alokasi pendanaan. Hal ini terbukti dengan upaya beberapa Lapas, seperti di Tasikmalaya dan Cilacap yang saat ini sedang mengembangkan pesantren. Upaya beberapa Lapas ini akhirnya tak membuahkan pesantren sebesar Pesantren Lapas Cianjur, sebab dukungan dana tidak maksimal. Niat baik HS untuk mewujudkan sebuah lembaga pembinaan bagi warga binaan LP disambut baik oleh semua pihak, baik pimpinan pemerintahan daerah, DPRD dan ormas keislaman yang terdapat di Cianjur. Inilah yang mempercepat dan memapankan pesantren hingga saat ini. Dukungan struktural juga terdapat pada keberadaan Peraturan Daerah (Perda) Gerbang Marhamah, yang merupakan Perda bernuansa syariat Islam. Perda ini menjadi payung legitimatif bagi pendirian pesantren dalam kerangka menciptakan masyarakat Lapas berakhlaqul karimah.

Gayung dari Lapas inipun disambut oleh para ulama Cianjur, khususnya yang berada di dalam MUI. Maka dua pemuka keagamaan terkemuka, seperti Ahmad Yani (Sekretaris MUI) dan KH T. Muchtar Ghozali (Pimpinan Pesantren Al-Istiqlal Cianjur) menyambut gagasan ini, dan mengkoordinasikan para pengajar yang mau mengajar di pesantren ini.

Berdasarkan keputusan kepala kantor Kementerian Agama Kabupaten Cianjur Nomor: Kd.10.03/PP.007/687/2012, Tanggal 17 September 2012, pesantren ini mendapat pengakuan dari Kementerian Agama Kabupaten Cianjur dengan Nomor Statistik Pondok Pesantren 510032030007. Artinya, secara legal formal lembaga yang 
menyelenggarakan pendidikan agama dan keagamaan di Lapas ini sebagai pesantren.

Pesantren At-Taubah disebut sebagai Pesantren Terpadu karena ia terpadu dengan pembinaan di Lapas secara integral. Artinya tidak ada keterpisahan antara pembinaan kepribadian yang di dalamnya pendidikan pesantren dengan pembinaan lain, yang menyebabkan kesatuan antara lembaga pesantren dan Lapasitu sendiri. Keterpaduan ini bisa dilihat dari keterpaduan pembinaan kepribadian (pesantren), pembinaan kemandirian dan pembinaan intelektual yang terlihat dalam kegiatan santri/warga binaan.

\section{Tujuan Pendirian}

Tujuan jangka panjang pendirian pesantren adalah: a) Menjadikan Lapas Cianjur sebagai Lapas Pusat Pendidikan Islam bagi WBP baik intern maupun ekstern WBP di luar Lapas Cianjur, b) Menghasilkan Ex-WBP yang mempunyai pengetahuan tentang Agama Islam dan menjadi Pelopor Deradikalisasi di masyarakat, c) Membangun stigma positif terhadap Lembaga Pemasyarakatan, WBP dan Ex-WBP dan d) Ex-WBP mudah diterima masyarakat karena terjadi transformasi jiwa, Ex-WBP bisa menjadi panutan masyarakat (contoh : ExWBP memiliki sertifikat dengan kompetensi mampu membaca Al-Qur'an, memahami Fiqih, Nahwu dan lain-lain).

Adapun tujuan jangka pendek pendirian pesantren adalah: a) Terwujudnya peserta binaan di Lembaga Pemasyarakatan yang mampu membaca Al-Qur'an dengan baik dan benar, b) Terwujudnya peserta binaan di Lembaga Pemasyarakatan yang mampu membaca Kitab Kuning, c) Terwujudnya peserta binaan di Lembaga Pemasyarakatan yang taat menjalankan ibadah yang wajib dan sunat, dan d) Terwujudnya peserta binaan di Lembaga Pemasyarakatan yang mampu mendakwahkan Islam kepada keluarga, kerabat, dan masyarakat pada umumnya.

\section{Struktur Organisasi}

Struktur Organisasi Pesantren Terpadu Lembaga Pemasyarakatan Klas IIB Cianjur diisi oleh orang-orang Pemda, MUI, dan Lapas. Struktur organisasi pesantren terdiri dari: Dewan Pembina, ketua, wakil ketua, sekretaris, wakil sekretaris, bendahara, pembina, dan rois santri. Dewan Pembina terdiri dari Bupati, Ketua DPRD, Kepala Lapas, Ketua MUI, dan para kyai. Dalam pengurus pelaksana terdiri dari pihak MUI, Lapas, dan warga binaan. Warga binaan dipimpin oleh seorang yang disebut rois.

Strukturorganisasi pesantren At-Taubah Lapas Kelas IIB Cianjur saat ini adalah sebagai berikut: Dewan Pembina terdiri dari : Bupati Kabupaten Cianjur, Ketua DPRD Kabupaten Cianjur, Kepala Lembaga Pemasyarakatan Cianjur, Ketua MUI Kabupaten Cianjur, KH. Inggi Badru Zaman, KH. Abdul Qodir Rozi, KH. M Yahya Soleh, H. Ahmad Yani, S.IP, H. Yosep Umar, SH, MM.

Sementara itu dalam kepengurusan harian meliputi : KH. Totoy Mukhtar Gozali, S.Sy (Ketua), Mastur, Amd.IP, SH, MM (Wakil Ketua), Drs. Nanang Gojali, M.Ag (Sekretaris), Deden Hendra, SH (Wk. Sekretaris), Suhandi, S.Pdi (Bendahara), Para Ustad/Assatid (Pembina), Heri Sukirman, SH. (Rois santri Pemasyarakatan).

\section{Kegiatan Pengajaran}

Kegiatan belajar dalam rangka pembinaan bersifat terpadu, antara pembinaan pesantren dan pelatihan life skill. Pengajian formal pesantren dibagi menjadi dua kelompok (kelas), meliputi Kelompok A mengaji Baca Tulis al-Qu'ran (BTQ) dan praktik ibadah. Kelompok A berjumlah 17 kelompok. Serta Kelompok B, yang telah 
lulus BTQ dan praktik ibadah, mengaji aqidah, syari'ah dan akhlaq. Kelompok B terdiri dari 8 kelompok. Namun secara garis besar, di dalam pengajian BTQ selalu diselipkan ajaran aqidah, syari'ah dan akhlaq sebagai pondasi dari pembinaan keagamaan. Pengajian formal ini dilakukan setiap hari Senin, Rabu dan Kamis, pukul $08.00-10.00$ menjelang siang.

Pengajian formal lainnya bersifat kolektif. Yakni istighostah bersama setiap Selasa pagi di Masjid At-Taubah. Istighostah diawali dengan sholat dluha, dzikir istighostah dan diakhiri oleh taushiyyah dari pimpinan pesantren, Kiai T. Mochtar Ghazali. Pengajian kolektif yang bersifat ritual muroqqobah juga dilakukan setiap malam jum'at dalam bentuk riyadloh; sholat hajat dan membaca Surat Yasin berjama'ah.

Sore hari diisi dengan pembinaan dalam rangka life skill, baik penjahitan, mebelair, tata boga dan PKBM Paket, B, C dan KF. Bagi yang tidak ikut kursus pembinaan, sering melakukan pendalaman pengajian di kamarkamar, khususnya pendalaman membaca alQur'an.

Dalam rangka pembinaan, Pesantren At-Taubah mewajibkan setiap warga binaan untuk mampu membaca al-Qur'an dan menghafal 10 surat pendek. Kemampuan ini menjadi syarat bagi penerimaan remisi, Pembebasan Bersyarat (PB) dan Cuti Menjelang Bebas (CMB).

Dengan pola pembelajaran bersifat formal dan informal, Pesantren AtTaubah telah mampu mengubah Lapas menjadi pesantren. Hal ini berdampak signifikan bagi para santri. Manfaat nyata dari pengajian pesantren terlihat dalam kemampuan membaca al-Qur'an dan praktik ibadah, terutama sholat. Sebab hampir 70\% warga binaan tidak bisa sholat ketika kali pertama masuk di Lapas, dan 97\% tidak bisa membaca al-Qur'an. Saat ini setelah mengalami pembelajaran kepesantrenan, presentasi tersebut berbalik. Hal ini terlihat dari antusiasme para santri untuk sholat berjamaah. Untuk dzuhur dan ashar berjama'ah di masjid. Sementara maghrib, isya', shubuh berjama'ah di kamar masingmasing. Di setiap kamar terdapat imam sholat, mu'adzin dan kepala kamar, sehingga setiap menjelang sholat maghrib, isya' dan shubuh, selalu terdengar adzan bersahutan dari setiap kamar. Sholat jama'ah di masjidpun menggambarkan fenomena yang fenomenal. Hampir sejam sebelum sholat, para santri telah memenuhi masjid dan membanjiri hingga di halaman masjid.

Selain kemampuan membaca alQur'an, Pesantren At-Taubah juga telah melahirkan para santri yang hendak menghafal al-Qur'an. Saat ini sudah ada 4 santri yang sedang menghafal al-Qur'an, rata-rata telah mencapai juz 2 hingga juz 3. Selain proses tahfidz, juga terdapat 6 santri yang memperdalam seni baca alQu'ran, dan group nasyid dalam kerangka pengembangan seni Islam. Keberhasilan pesantren menumbuhkan semangat menghafal al-Qur'an merupakan titik puncak keberhasilan pembelajaran, sebab ia menggambarkan titik nadir kesadaran para santri. Jika dirangkum keterpaduan antara kegiatan pembinaan kepribadian, pembinaan kemandirian, dan pembinaan intelektual adalah sebagai berikut:

Pertama : kegiatan mengaji setiap Senin, Rabu dan Kamis pukul 08.00-10.00, bentuk kegiatannya adalah : a) Baca Tulis al-Qur'an (BTQ) dan praktik ibadah, untuk Kelas A berjumlah 17 kelompok, b) Aqidah, Syariah dan Akhlaq, untuk Kelas B berjumlah 8 kelompok.

Kedua, Dzikir bersama setiap Selasa pagi: Sholat dluha berjamaah, istigostah dan taushiyah. Semuanya dilakukan oleh seluruh warga binaan di Masjid At-Taubah. Ketiga, Pembacaan Surat Yasin dan Riyadloh bersama setiap malam jum'at. 
Keempat, PKBM dalam bentuk kejar Paket C (setara SMU), Paket B (SMP) dan Paket KF (SD). Pelatihan Ketrampilan menjahit: Pakaian, sablon dan potong rambut. Kelima, pemberian life skill warga binaan: Membuat kandang ayam, Peternakan (kelompok tani): Penetasan Itik, Pelatihan ketrampilan Tata boga (bagi kelompok wanita): Pembuatan telor asin. Keenam : kegiatan Olah raga:Team futsal, volley ball, tenis meja dan senam kesegaran jasmani. Ketujuh : Penyuluhan kesehatan HIV/AIDS dan tes narkotika.

\section{Pengajar atau Ustadz}

Pengajar di pesantren At-Taubah berjumlah 33 orang dan ada sekitar 9 orang sebagai cadangan. Dari 33 orang tersebut sebanyak 25 orang kami berikan angket. Dari penyebaran angket itu didapat data sebagai berikut. Seluruh pengajar berasal dari Cianjur. Dilihat dari tempat lahir sebagian besar (48\%) lahir di Cianjur. Sisanya tersebar di beberapa wilayah di Jawa Barat. Ada sekitar $8 \%$ pengajar yang lahir di Lampung. Namun ada sekitar $16 \%$ yang tidak menyebutkan dimana mereka lahir.

Usia pengajar cukup beragam. Sebagian besar (40\%) berusia antara 37-42 tahun. Diikuti usia 25-30 tahun sebesar (24\%) dan usia 31-36 tahun sebesar (16\%). Jika dijumlah usia antara 25-42 sebanyak (80 \%), maka data ini menunjukkan pengajar di pesantren At-Taubah dapat dikatakan sebagian besar tergolong muda. Tetapi ada sekitar $4 \%$ yang berusia 67-72 tahun.

Dilihat dari pendidikan terakhir, sebanyak (32 \%) pengajar berpendidikan terakhir SMU dan (24\%) berpendidikan terakhir SLTP. Bahkan (4\%) berpendidikan terakhir SD. Ini artinya, sebagian besar (60\%) berpendidikan terakhir SMU ke bawah. Hanya (24\%) yang berpendidikan terkahir dari D4 sampai S2. Namun sebagian besar pengajar (56\%) adalah alumni pesantren. sisanya (40\%) bukan alumni pesantren dan (4\%) tidak diketahui apakah alumni pesantren atau tidak.

Pekerjaan pengajar beragam. Selain sebagai pengajar di pesantren At-Taubah, mereka bekerja sebagai guru pesantren (20\%), guru (16\%), pimpinan pesantren (12\%), guru majlis taklim (16\%), wiraswasta (8\%), guru diniyah (4\%), guru ngaji (4\%), dan guru TPA (4\%). Selain itu ada juga pekerjaan pengajar sebagai anggota polri (4\%), jurnalis, dosen (4\%), dan pensiunan Pemda (4\%).

Dilihat dari aktif dan tidaknya pengajar di organisasi, sebagian besar (68\%) pengajar aktif di organisasi dan sisanya (32\%) menyatakan tidak aktif di organisasi. Dari sejumlah pengajar yang aktif di organisasi, sebanyak (47\%) aktif di organisasi Hamida (Himpunan Miftahul Huda). Organisasi ini merupakan himpunan alumni pesantren Miftahul Huda Manonjaya Tasikmalaya. Pesantren ini didirikan oleh almarhum $\mathrm{KH}$ Choer Affandi. Ia adalah seorang ulama kharismatik dan tokoh pergerakan Islam (DI). Saat ini pesantren ini dipimpim oleh KH Asep Maushul Affandi dan KH Abdul Aziz Affandi. Pesantren ini tergolong pesantren Salafiyah. Sekitar kurang lebih 1000 cabang pesantren Miftahul Huda yang tersebar umumnya di daerah Jawa Barat dan daerahdaerah lainnya di Indonesia. Di Cianjur sendiri, pesantren yang berafiliasi dan mengidentifikasikan diri kepada pesantren Miftahul Huda Tasikmalaya cukup banyak sekitar 400 pesantren. Diantaranya adalah pengasuh pesantren At-Taubah Lapas Cianjur, yaitu: K.T. Muchtar Ghozali. Tenaga pengajar selain berasal dari organisasi Hamida, terdapat juga organisasi DTA, FPI, IKAPI, MUI, Matlaul Anwar, Muhamadiyah, Persis, dan Syarikat Islam. 
Tabel:1

Organisasi Yang diikuti Pengajar

\begin{tabular}{|l|c|c|}
\hline \multicolumn{1}{|c|}{ organisasi yang diikuti } & frekuensi & \% \\
\hline Hamida & 8 & 47 \\
\hline DTA & 1 & 6 \\
\hline FPI & 1 & 6 \\
\hline IKAPI & 1 & 6 \\
\hline MUI & 1 & 6 \\
\hline Matlaul Anwar & 1 & 6 \\
\hline Muhamadiyah & 1 & 6 \\
\hline Persis & 1 & 6 \\
\hline Syarikat Islam & 1 & 6 \\
\hline tidak menyebutkan & 1 & 6 \\
\hline Jumlah & $\mathbf{1 7}$ & $\mathbf{1 0 0}$ \\
\hline
\end{tabular}

Sumber: penyebaran angket penelitian pesantren At-Taubah 29-01-2013

\section{Kurikulum}

Tidak ada kurikulum resmi yang digunakan. Para pembina pesantren membuat kurikulum sendiri. Secara umum kurikulum yang digunakan mengacu kepada kurikulum Iqra dan pesantren Mifathul Huda Manonjaya Tasikmalaya. Untuk kelompok A difokuskan kepada materi BTQ dan praktek shalat, dan untuk kelompok B difokuskan kepada materi Aqidah, Ibadah dan Mua'amalah, sertta Nahwu dan Sharaf. Buku yang digunakan adalah buku iqra karangan ustadz As'ad Humam. Sedangkan buku yang digunakan untuk kelompok B adalah kitab-kitab kuning. Selain itu digunakan buku Satuan Pelajaran Madrasah Diniyah Hamida. Satuan pelajaran ini disusun oleh Departemen Pendidikan Hamida Pesantren MiftahulHudaTasikmalaya.Satuan Pelajaran ini terdiri dari Tauhid, Syahadatain, Fiqih, Al-Qur'an, Tarikh dan Akhlak.

Tauhid meliputi: Aqoid Iman, sifat yang wajib, mustahil dan jaiz bagi Allah, Sifat yang wajib, mustahil, dan jaiz bagi Rasul. Syahadatain meliputi: bacaan syahadatain, ma'rifat, tasdiq, shigat tasdiq, rukun Islam, dan rukun Iman. Fiqih meliputibersuci, wudhu, rukun shalat, rakaat shalat, dan praktek wudhu dan shalat. Al-Qur'an meliputi: membaca dan menulis al-Qur'an dan hafalan. Tarikh meliputi sejarah rasul. Akhlak meliput: akhlak kepada orang tua, akhlak kepada guru, dan doa-doa pesantren.

Kelompok B juga menggunakan kitab kuning. Untuk materi Aqidah digunakan kitab Tijan ad-Dirari, materi ibadah digunakan kitab Safinah an-Najah, dan materi nahwu sharaf digunakan kitab Nahwul Wadhih.

\section{Santri}

Setiap warga binaan yang akan menjadi santri melalui beberapa tahapan, yaitu: proses administrasi, pemeriksaan kesehatan, sekretariat pesantren, dan kamar orientasi. Setelah dilakukan pendaftaran administrasi, seorang warga binaan diperiksa kesehatannya. Selanjutnya oleh pihak penyelenggara di tes untuk dikelompokkan, apakah masuk kelompok A yang belajar Baca Tulis al-Qur'an (BTQ) dan Praktek ibadah atau masuk kelompok B yang belajar Aqidah, Ibadah, Akhlak.

Santri pesantren At-Taubah per 30 Januari 2013 sebanyak 800 orang. Santri terbagi kepada beberapa kelompok belajar, yaitu: (1) Santri BTQ dan Praktek Ibadah, (2) Santri Aqidah, Syariah, dan Akhlak, (3) Santri Qira'at dan Akhlak.

Tabel: 2

Jumlah Kelompok belajar dan jumlah santri

\begin{tabular}{|l|c|c|c|c|}
\hline \multicolumn{1}{|c|}{$\begin{array}{c}\text { kelompok } \\
\text { belajar }\end{array}$} & $\begin{array}{c}\text { jumlah } \\
\text { kelompok }\end{array}$ & $\%$ & $\begin{array}{c}\text { jumlah } \\
\text { santri }\end{array}$ & $\%$ \\
\hline $\begin{array}{l}\text { santri BTQ dan } \\
\text { Praktek Ibadah }\end{array}$ & 16 & 64 & 541 & 68 \\
\hline $\begin{array}{l}\text { santri Aqidah, } \\
\text { Syariah, dan } \\
\text { Akhlak }\end{array}$ & 8 & 32 & 235 & 29 \\
\hline $\begin{array}{l}\text { Santri Qira'at } \\
\text { dan Akhlak }\end{array}$ & 1 & 4 & 24 & 3 \\
\hline Total & $\mathbf{2 5}$ & $\mathbf{1 0 0}$ & $\mathbf{8 0 0}$ & $\mathbf{1 0 0}$ \\
\hline
\end{tabular}

Sumber: sekretariat pesantren At-Taubah 
Dari 541 santri kelompok BTQ dan praktek ibadah sebanyak 9 kelompok Iqro 1-3 dengan jumlah 294 santri dan sebanyak 7 kelompok Iqra 4-6 dengan jumlah santri 247 santri.

Tabel: 3

Rincian Jumlah kelompok dan Santri BTQ dan praktek ibadah

\begin{tabular}{|c|c|c|c|c|}
\hline $\begin{array}{c}\text { kelompok } \\
\text { belajar }\end{array}$ & $\begin{array}{c}\text { jumlah } \\
\text { kelompok }\end{array}$ & \% & $\begin{array}{c}\text { jumlah } \\
\text { santri }\end{array}$ & \% \\
\hline Iqra 1-3 & 9 & 56,3 & 294 & 54,3 \\
\hline Iqra 4-6 & 7 & 43,8 & 247 & 45,7 \\
\hline Total & $\mathbf{1 6}$ & $\mathbf{1 0 0}$ & $\mathbf{5 4 1}$ & $\mathbf{1 0 0}$ \\
\hline
\end{tabular}

Sumber: sekretariat pesantren At-Taubah

Berdasarkan angket yang kami sebarkan kepada 745 santri dari 800 santri dapat dibuat beberapa karakteristik. Karakteristik pertama, adalah berdasarkan usia santri. Usia antara 26-35 tahun sebesar $38 \%$, antara 16-25 tahun sebesar 31\%, antara 36-45 tahun sebesar $16 \%$, antara $46-55$ tahun sebesar7\%, antara 56-65 tahun sebesar $3 \%$, antara 6675 tahun sebesar $1 \%$ dan tidak menjawab sebesar $4 \%$. Jika dijumlahkan kelompok usia 16-25, usia 26-35 dan usia 36-45 \% didapat sebanyak $85 \%$. Artinya, dapat dikatakan usia santri sebagian besar tergolong muda. Karakteristik kedua, adalah berdasarkan jenis kelamin santri. Laki-laki sebesar 98,7 \% dan perempuan sebesar 1,3\%.

Tabel: 4

usia santri pesantren At-Taubah

\begin{tabular}{|c|c|c|}
\hline Usia & jumlah & \% \\
\hline $16-25$ & 230 & 31 \\
\hline $26-35$ & 283 & 38 \\
\hline $36-45$ & 118 & 16 \\
\hline $46-55$ & 51 & 7 \\
\hline $56-65$ & 23 & 3 \\
\hline $66-75$ & 6 & 1 \\
\hline $76-85$ & 1 & 0 \\
\hline tidak menjawab & 33 & 4 \\
\hline Total & $\mathbf{7 4 5}$ & $\mathbf{1 0 0}$ \\
\hline
\end{tabular}

Sumber: Hasil Olah angket penelitian
Karakteristik ketiga, adalah berdasarkan pendidikan terakhir. Didapatkan data 49,1 \% berpendidikan terakhir SD, $27 \%$ berpendidikan terakhir SMP, 13,4 \% berpendidikan terakhir SMA, 6,3 \% berpendidikan terkahir SMK, $0,1 \%$ berpendidikan terakhir MTs, 0,1 \% berpendidikan terakhir MA, 1,9 \% berpendidikan terakhir S1, 0,3 \% berpendidikan terakhir D3, 0,4 \% berpendidikan terakhir KF, dan 0,1 \% berpendidikan terakhir Paket B. Data ini menunjukkan 96,6 \% santri berpendidikan terakhir SMA ke bawah. Meskipun demikian mereka masih memiliki peluang untuk menyelesaikan pendidikan yang lebih tinggi pasca keluar dari Lapas.

Tabel: 5

pendidikan terakhir santri pesantren At-Taubah

\begin{tabular}{|c|c|c|}
\hline Pendidikan terakhir & Jumlah & $\%$ \\
\hline SD & 366 & 49,1 \\
\hline SMP & 201 & 27 \\
\hline MTs & 1 & 0,1 \\
\hline SMA & 100 & 13,4 \\
\hline SMK & 47 & 6,3 \\
\hline MA & 1 & 0,1 \\
\hline S1 & 14 & 1,9 \\
\hline D3 & 2 & 0,3 \\
\hline $\mathrm{KF}$ & 3 & 0,4 \\
\hline Paket B & 1 & 0,1 \\
\hline Tidak Menjawab & 9 & 1,2 \\
\hline Total & 745 & 100 \\
\hline
\end{tabular}

Sumber: penyebaran angket penelitian pesantren AtTaubah 29-01-2013

Karakteristik keempat, adalah berdasarkan status di Lapas. Sebanyak $84 \%$ santri berstatus Napi, 15,6 \% berstatus tahanan, dan sisanya 0,4 \% tidak diketahui statusnya apakah Napi atau tahanan. 
Tabel: 6

Status santri pesantren At-Taubah

\begin{tabular}{|l|c|c|}
\hline \multicolumn{1}{|c|}{ Status } & jumlah & \% \\
\hline Napi & 626 & 84 \\
\hline Tahanan & 116 & 15,6 \\
\hline Tidak Menjawab & 3 & 0,4 \\
\hline & $\mathbf{7 4 5}$ & $\mathbf{1 0 0}$ \\
\hline
\end{tabular}

Sumber: penyebaran angket penelitian

pesantren At-Taubah 29-01-2013

Karakteristikkelima,adalahberdasarkan kasus. Dari 626 santri yang berstatus napi sebanyak 29 \% kasus KDRT, 26,8 \% kasus narkoba, 17,4 \% kasus pencurian, 6,5 \% kasus perampokan, 4,5\% kasus penipuan, 3,4 \% kasus penggelapan, 1,8 \% kasus ilegal loging. Sisanya terjerat kasus penadahan, penganiayaan, aborsi, pemalsuan uang, korupsi, pemerkosaan, melarikan wanita, tindak kekerasan, dan lainnya.

Karakteristik keenam, adalah berdasarkan lama dipidana bagi yang berstatus Napi. Dari 626 yang berstatus Napi sebanyak 50,8 \% dipidana antara 0-4,7 tahun. Sebanyak 41,1 \% dipidana antara 4,8- 9,4 tahun, dan 6,9 $\%$ dipidana antara 9,5 - 14 tahun.

Tabel:7

Lama di pidana

\begin{tabular}{|c|c|c|}
\hline lama pidana & jumlah & \% \\
\hline $0-4,7$ tahun & 318 & 50,8 \\
\hline $4,8-9,4$ tahun & 257 & 41,1 \\
\hline $9,5-14$ tahun & 43 & 6,9 \\
\hline tidak menjawab & 8 & 1,3 \\
\hline Total & $\mathbf{6 2 6}$ & $\mathbf{1 0 0}$ \\
\hline
\end{tabular}

Sumber: penyebaran angket penelitian pesantren At-Taubah 29-01-2013

\section{Sarana dan Prasarana}

Tempat pembelajaran di Pesantren At-Taubah masih memanfaatkan fasilitas seadanya. Untuk pengajian formal diadakan baik di kamar-kamar sel penjara, meliputi 11 kamar dari 27 kamar tahanan dan narapidana. Selain di kamar sel, pengajian juga diadakan di Masjid At-Taubah yang ada di dalam Lapas, serta di aula pertemuan para pengurus Lapas. Pemanfaatan fasilitas seadanya menunjukkan semangat yangbesar bagi warga Lapas untuk memaksimalkan pembinaan pesantren.

\section{Output atau Hasil Kegiatan Pesantren}

Dari informasi yang diperoleh para pengajar (Pembina) Pesantren Terpadu At-Taubah Lembaga Pemasyarakatan Klas IIB Cianjur pada saat mengadakan pengajian diluar di masyarakat ada yang menyampaikan dan menanyakan eksistensi pesantren di Lembaga Pemasyarakatan Klas IIB Cianjur. Ada perbedaan kemampuan warga binaan antara sebelum masuk dan sesudah keluar Lembaga Pemasyarakatan Klas IIB Cianjur misalnya sebelum masuk tidak bisa baca al-qur'an, dan setelah keluar bisa membaca al-Quran.

Pihak penyelenggara menceritakan kepada penulis bahwa ada mantan santri Pesantren Terpadu Lembaga Pemasyarakatan Klas IIB Cianjur yang setelah keluar, aktif dan mengajar di: DKM Mesjid Agung Kabupaten Cianjur, PAI di SMK Siliwangi Cianjur, privat atau panggilan ke rumah, dan sekarang aktif mengajar Qiroat di Pondok Pesantren Terpadu At-Taubah Lembaga Pemasyarakatan Klas IIB Cianjur.

\section{Surat Keterangan dan Sertifikat}

Pesantren Terpadu At-Taubah Lembaga Pemasyarakatan Klas IIB Cianjur mengeluarkan Surat Keterangan dan Sertifikat bagi santri/WBP yang telah selesai mengikuti pesantren/habis menjalani masa pidananya dengan ketentuan sebagai berikut: (1) Masa pidana 1 bulan s/d 6 bulan santri /wbp akan diberikan Surat 
Keterangan telah mengikuti Pesantren Terpadu di Lembaga Pemasyarakatan Klas IIB Cianjur; (2) Masa pidana 6 bulan s/d 1 tahun akan diberikan sertifikat yang menerangkan telah mengikuti pelajaran selama didalam Lembaga Pemasyarakatan atau Pesantren Terpadu At-Taubah Lembaga Pemasyarakatan Klas IIb Cianjur; (3) Masa pidana 1 tahun keatas akan diberikan sertifikat yang menerangkan pelajaran yang telah diikuti dengan nilai hasil evaluasi pembelajaran di Pondok Pesantren Terpadu At-Taubah Lembaga Pemasyarakatan Klas IIB Cianjur.

Surat Keterangan dan Sertifikat dikeluarkan oleh Pesantren Terpadu AtTaubah Lembaga Pemasyarakatan Klas IIB Cianjur diketahui oleh Kepala Lembaga Pemasyarakatan Klas IIB Cianjur dan disetujui oleh Ketua MUI Kab.Cianjur.

\section{Menakar Pesantren At-Taubah sebagai Model Pembinaan Lapas}

Pesantren At-Taubah Lapas Kelas IIB Cianjur memang bukan pesantren pada umumnya yang berkonsentrasi pada pengembangan keilmuan Islam. Ia lebih merupakan pesantren terapi dan pendidikan keagamaan dalam rangka pembentukan kepribadian muslim. Hal ini tercermin dari nama pesantren itu sendiri, At-Taubah yang artinya pertaubatan: kembali kepada-Nya. Maka Pesantren At-Taubah merupakan proses pendidikan demi pertaubatan hidup.

Proses pembentukan kembali pribadi muslim ini terlihat dalam kesadaran para pengurus pesantren yang juga merupakan pengurus Lapas, bahwa kriminalitas yang dilakukan para warga binaan, salah satunya disebabkan oleh minimnya pengetahuan agama. Pemahaman ini ditemukan setelah proses pendidikan berjalan selama hampir setahun ini, ketika ditemukan fakta bahwa hampir $70 \%$ warga binaan tidak bisa sholat.
Kewajiban belajar baca al-Qur'an dan praktik ibadah menyiratkan pendidikan paling dasar di dalam Islam, sebagai pintu masuk bagi pemahaman keislaman lebih dalam.

Hanya saja, pesantren ini juga tidak hanya menyediakan pendidikan dasar agama, tetapi juga pemahaman lebih lanjut mengenai aspek-aspek dasar (ushul aldin) dari Islam. Adanya pengajian aqidah, syari'ah dan akhlaq di dalam Kelompok B menyiratkan pengembangan pendidikan Islam lebih lanjut. Apalagi melalui penggunaan kitab kuning klasik, seperti Sullam al-Taufiq yang menempatkan Pesantren At-Taubah, benar-benar sebagai pesantren. Yang menarik di dalam pesantren ini memang tidak terletak pada proses didaktik formal maupun cakupan kurikulum yang masih terbatas. Melainkan kehidupan keagamaan yang "subur" yang menyiratkan semangat hidup dari para santri. Hal ini terlihat di dalam praktik ibadah, terutama sholat yang selalu berjamaah. Baik di masing kamar sel maupun di masjid, jamaah sholat selalu penuh hingga membanjiri halaman masjid. Hal ini menjadi pemandangan yang mengharukan, mengingat semangat ini terjadi di sebuah lembaga pemasyarakatan. Adzan yang saling menyahut dari masing sel juga menyajikan semangat kehidupan Islami yang kuat, dan akhirnya mampu menampilkan kehidupan Lapas yang benarbenar berbeda dengan Lapas biasanya.

Keberhasilan pesantren ini juga terdapat pada penumbuhan kesadaran dari sebagian kecil warga binaan untuk mendalami alQur'an dalam proses tahfidz. Artinya, pesantren telah mampu menumbuhkan kesadaran mendasar di kalangan warga binaan untuk tidak memaknai masa hukuman di Lapas sebagai hukuman, melainkan sebagai proses pertaubatan menuju kepribadian muslim yang berarti. Beberapa santri yang berketetapan hati menjadi hafidz bahkan mensyukuri 
keberadaan mereka di Lapas, sebab dengan keberadaan ini mereka bisa menghabiskan waktu menghafal al-Qur'an. Kesadaran ini merupakan titik balik, dari kejahatan menjadi pertaubatan.

Dengan keberhasilan pendidikan pesantren dalam "menyulap" Lapas, menjadi pesantren. Tak heran jika Lapas Klas IIB Cianjur ini menjadi Lapas unggulan berbasis pesantren. Hal ini telah membuahkan dua kebaikan sekaligus. Pertama, masuknya pesantren dan para pengajar agamake "dunia gelap" kejahatan, yang selama ini dijauhi oleh kaum agamawan. Pesantren At-Taubah telah menunjukkan "arus balik" keagamaan, dengan berbondong-bondongnya para ustdaz dan kiai untuk berebut mengajar di pesantren ini. Mereka terinspirasi oleh tauladan Nabi Muhammad SAW yang telah menunjukkan cahaya (al-huda) di tengah kegelapan masyarakat jahiliyyah. Lapas yang berisi para kriminal merupakan masyarakat jahiliyyah yang membutuhkan cahaya agama. Di dalam proses pengajaran, terlihat betapa para ustadz dan kiai begitu semangat di dalam memberikan penyadaran keagamaan kepada para santri binaan. Kedua, revolusi pembinaan atas kriminalitas berbasis pesantren. Model pembinaan yang ada di Lapas konvensional terbukti kurang efektif di dalam pembentukan kesadaran para terhukum. Hal ini terjadi sebab pembinaan cenderung terfokus pada pelatihan kerja, sementara problem akut para narapidana sebenarnya terletak pada moralitas. Pembinaan agama dalam bentuk majelis ta'lim secara berkala terbukti tidak efektifbagi proses penyadaran. Hal ini terjadi karena penyadaran keagamaan memang membutuhkan pendidikan intensif, baik di dalam kelas, terlebih di ruang kehidupan para santri. Dengan adanya pesantren, pendidikan agama tidak terhenti pada pengajaran klasikal, melainkan pembinaan di dalam praktik hidup keseharian. Maka secara tidak langsung, Pesantren At-Taubah telah membentuk Islam tidak hanya sebagai sistem pendidikan, melainkan terlebih sistem budaya. Artinya, tata pendidikan Islam telah diintegralkan dengan tata subkemasyarakatan di Lapas tersebut. Hal ini terlihat pada sifat Pesantren At-Taubah sebagai pesantren terpadu.

\section{PENUTUP}

Studi ini dapat disimpulkan: pertama, Pesantren at-Taubah merupakan lembaga pendidikan keagamaan yang berada di dalam lembaga pemasyarakatan, secara legal formal telah diakui sebagai pesantren oleh Kementerian Agama. Kegiatan pesantren dilakukan secara terpadu dan integral dengan pembinaan di Lapas. Keterpaduan ini dalam keterpaduan pembinaan kepribadian (pesantren), pembinaan kemandirian dan pembinaan intelektual yang terlihat dalam kegiatan santri/warga binaan.

Kedua, penyelenggaraan Pesantren AtTaubahLapas Klas IIBCianjursebagai institusi pendidikan, memang bukan pesantren pada umumnya yang berkonsentrasi pada pengembangan keilmuan Islam. Pesantren ini lebih merupakan pesantren terapi dan pendidikan keagamaan dalam rangka pembentukan kepribadian muslim, muncul karena adanya kesadaran akan minimnya pengetahuan agama di LP. Bentuk dan pengelolaan pesantren disesuaikan dengan kondisi di Lingkungan LP. Kurikulum yang diajarkan masih terbatas kepada pendidikan dasar agama, aspek-aspek dasar (ushul al-din) dari Islam, penekanan pada BTQ, ritual ibadah sehari-hari (shalat jamaah), doa/zikir, Tahfidzul Qur'an. Kegiatan pembelajaran dilakukan secara sorogan, bandongan dan diskusi.

Selanjutnya dari kesimpulan ini, dapat direkomendasikan sebagai berikut: Pertama, Pendidikan keagamaan berbasis 
pesantren di Lapas Kelas IIB Cianjur dapat dijadikan sebuah model pesantren yang bisa diterapkan di Lapas lainnya. Jika akan diterapkan di Lapas-Lapas lain harus datang dari inisiatif warga binaan. Kemudian direspon oleh MUI, Ormas Keagamaan, Kemenag, dan pihak Lapas sendiri.

Kedua, perlunya dilakukan pembinaan secara kontinyu dan intensif bagi alumni pesantren At-Taubah yaitu melalui penitipan kepada para tokoh setempat, MUI, pesantren (khususnya pesantren yang mengembangkan program life skill), sehingga para alumni dapat benar-benar diterima oleh warga masyarakat biasa dan bermanfaat bagi lingkungan sekitarnya.

\section{UCAPAN TERIMAKASIH}

Ucapan terimakasih penulis sampaikan kepada berbagai pihak yang telah membantu proses pelaksanaan penelitian sampai pelaporannya, terutama Kepala Puslitbang Penda yang telah mempercayakan kami untuk melaksanakan penelitian. Kepada Prof. Dr. Muhammad Hisyam dan Dr. Muhaimin AG, MA, Penulis ucapkan terima kasih atas koreksian dan masukan kritisnya terhadap tulisan ini. Penulis juga ucapkan terima kasih kepada sdr. Syaiful Arif yang telah membantu dalam pengumpulan data di lapangan, sehingga penelitian ini dapat terlaksana.

\section{DAFTAR PUSTAKA}

Ainurrohmah, Leni. (2013): Pembinaan Bagi Narapidana Pelaku Kejahatan Narkotika Di Lembaga Pemasyarakatan Narkotika Klas II A Yogyakarta. Diss. UIN Sunan Kalijaga Yogykarta.

Handayani, T. P. (2010): Kesejahteraan Psikologis Narapidana Remaja di Lembaga Pemasyarakatan Anak Kutoarjo. Semarang, Jawa Tengah, Universitas Diponegoro.

Puslitbang pendidikan Agama dan Labsosio UI (2010): Laporan Hasil Penelitian Penyelenggaraan Pendidikan Keagamaan pada Kelompok Khusus. Jakarta, Puslitbang Pendidikan Agama dan Keagamaan

Ratnawati, G. (2010): Pola Pembinaan NAPI Anak Sebagai Salah Satu Upaya Pemenuhan Kebutuhan Pendidikan di Lembaga Pemasyarakatan Anak. Malang, Fakultas Ilmu Pendidikan Universitas Negeri Malang.

Silawaty, I., \& Ramdhan, M. (2007): Peran agama terhadap penyesuaian diri narapidana di dalam lembaga pemasyarakatan. JPS,

Syafi'i, Ahmad (1991): Pembinaan Keagamaan Narapidada di Lembaga Pemasayarakatan. Jakarta, Balai Litbang dan Kemasyarakatan Departemen Agama RI

Sutarman, S (1991): Pembinaan Keagamaan Narapidana; Studi Kasus pada Lembaga Pemasyarakatan Sukamiskin Bandung. Jakarta, Balai Litbang dan Kemasyarakatan Departemen Agama RI

Yuanita. Rani (2011): Pembinaan Narapidana Melalui Pendidikan Agama sebagai Upaya Mencegah Munculnya Residivis di Lembaga Pemasyarakatan Narkotika Yogyakarta. Disertasi Fakultas Ilmu Sosial UNY 
Zakaria, Rusydy (1991): Pembinaan Keagamaan Narapidana; Studi Kasus pada Lembaga Pemasyarakatan Sukamiskin Bandung. Jakarta, Balai Litbang dan Kemasyarakatan Departemen Agama RI

UU Nomor 12 tahun 1995 tentang Pemasyarakatan

PP Nomor 32 tahun 1999 tentang Syarat dan Tata Cara Pelaksanaan Hak Warga Binaan Pemasyarakatan.

PP Nomor 55 Tahun 2007 tentang Pendidikan Agama dan Keagamaan

Wawancara dengan Kasubsi Registrasi dan Bimkemas Lapas kelas II B Cianjur, Mastur SH, pada 4 Februari 2013
Wawancara dengan Ahmad Yani, Sekretaris MUI Kabupaten Cianjur, pada 6 Februari 2013

Wawancara dengan KH Totoy Mukhtar Gozali dan para Ustadz, Pengasuh Pesantren Attaubah, 3 Februari 2013

Wawancara dengan para Warga Binaan LP Kelas II B Cianjur, 3 - 6 Februari 2013

Wawancara dengan Rais 'Am pesantren sekaligus santri, Heri Sukirman, SH, 5 Februari 2013 